\title{
E-Learning in COVID-19 Situation: Students' Perception
}

\author{
Geminastiti Sakkir ${ }^{\mathrm{a},}$, Syarifuddin Dollah ${ }^{\mathrm{a}}, \&$ Jamaluddin Ahmad ${ }^{\mathrm{b}}$ \\ ${ }^{a}$ English Education Department, Universitas Negeri Makassar, Indonesia \\ ${ }^{b}$ Universitas Muhammadiyah Sidenreng Rappang, Indonesia
}

\begin{abstract}
COVID-19 pandemic era has changed human life in the world. In education side, the learning process is forced to be carried out through full online (E-learning) since this pandemic era. There are many studies conducted on students' perceptions of using Elearning to learn the English language while this challenges era. So, the researchers also want to conduct a study about it. The objective of this study was to investigate the students' perceptions on the use of E-learning while COVID-19 pandemic era. Data were collected using a questionnaire that collected background information of participants and a five-point Likert scale to gauge the students' perception use of the E-learning in EFL classroom while pandemic COVID-19 era. Findings from this research indicate that the most of students showed a negative perception toward to use E-learning in the EFL process. It was proved by the results of students' perception. There is only 1 student who strongly agrees with the current e-learning process or said that the Elearning in pandemic COVID-19 era is effective, there are 10 students who said the E-learning is less effective, 1 students say they are moderate (4\%), 12 students said E-learning is not effective and 3 student said E-learning is very not effective. There are many factors influenced the students' perception on the use of E-learning media in COVID-19 pandemic era such as, the signal and network connection; limit of quota and expensive; lack of lecturers methods; lack of students' motivation; limitation of time; and lack of interaction.
\end{abstract}

Keywords: E-learning; students; perceptions; COVID-19; pandemic era.

\section{Introduction}

The outbreak of the COVID-19 virus in the world causes great anxiety and change for almost everyone around the world. The virus that has begun to develop in Wuhan, China has begun to be declared by the World Health Organization (WHO) as the current world pandemic since 2020. In tackling the COVID-19 virus, the government has made several policies such as carrying out physical distancing and even locking down in several areas. This policy has an impact on all aspects of life, including the field of education. This policy makes learning full online. The impact of this policy, the lecturers became panicked and shocked, because they had to change the learning methods and models so that the material was conveyed properly to the students. Learning through E-learning media is one of the best solutions during the COVID-19 pandemic. E-learning stands for Electronic Learning where learning is based on electronics or using electronic devices. Learning in the form of technology or assisted by computer-based devices and internet e-learning provides space and opportunities for students to learn creatively and actively understand teaching material (Sakkir, 2020).

E-Learning is expected to encourage students to be independent at certain times and be responsible for their learning (Stone \& Logan, 2018). In addition, e-learning will allow students to play a more dominant role in learning because it focuses on individuals, which includes the ability to adapt to the skill level of students and accumulate knowledge resources as mutual support (Conference, Jamin, \& Mudra, 2019). In addition, students' adaptive attitude will provide space and flexibility in self-organization so that it can encourage success and achievement in learning (Pratama \&

\footnotetext{
* Corresponding author.

E-mail address: hj.geminastitisakkir@yahoo.com (Geminastiti Sakkir)
} 
Yusro, 2016). There are many e-learning media that lecturers can use in teaching during this pandemic, such as social media, Facebook, WhatsApp, YouTube, LMS, Zoom, Google Classrooms, and other e-learning applications (Sakkir, 2020; Maulina, 2019). Therefore, in this study the researchers wanted to see whether the E-learning process was effective or not according to students' perceptions.

\section{Purpose of the study}

This study aims at answering the following questions:

1. What is students' perception on the use of E-learning Media in COVID-19 pandemic era?

2. What are the factors affecting the use of E-learning in the classroom?

\section{Literature Review}

\subsection{Technology as a Tool for Learning English}

Although schools are embedded with culture and reflect their values, technological changes that have engulfed society in general have left the education system largely unchanged (Syatriana, 2020). Laptops, videos, and other technologies, engage children with the immediacy that they use in their daily lives. With the emergence of theoretical awareness related to learning and an emerging interest in how new technologies can change the way teachers and children learn, there is scope, perhaps even real need, to see what is currently known about learning, especially in relation to it with the new possibilities provided by Information and Communication Technology (Sakkir, 2018).

Technology is a tool that is used to facilitate the learning process for various students, including EFL classes. In particular, educator shaving shows that the use of audio blogs contributes to increased opportunities to practice English speaking skills in the classroom (Hsu, Wang, \& Comac, 2008). Offering students oral assignments offer educators greater opportunities to assess students' speech development, and the methods applied can be adapted to meet the needs of a variety of students. Students can use their cell phones for these recorded tasks, indicating that there is a low-tech barrier to this practice. Students are asked to answer questions in a variety of forms, including interviews, surveys, and open-ended questions, and the accessibility of the corded blog makes it too easy for educators to judge the quality of the English used by their students.

There are many technological tools available to enable the learning of English by action. In fact, one of the techniques that have been applied is the use of shooting along with phrases to identify the subject associated with the photo in English. This technique is advantageous because it offers students the ability to describe images captured through the use of cell phone, camera, or social media technology, and it will help them associate their knowledge of these subjects with existing knowledge and promote learning process (Liu \& Chen, 2014). This system has been shown to be more effective for people who use mobile-assisted language learning techniques compared to those who don't. Although the increase may just be due to increased engagement, statistics show that this technique actually improves the quality of English learning.

\subsection{The Use of E-learning for Learning English in COVID-19 Situation}

During the pandemic COVID-19 era, it is undeniable that all students and lecturers experience confusion in carrying out the learning process (Atmowardoyo, 2020). With the situation that came suddenly and whole campus were temporarily closed, lecturers and students were forced to study from home. Therefore, there is a need for a solution to connect students and lecturers in order to carry out learning process even though they cannot meet directly at campus. The changes forced by pandemic COVID-19 era have been so fast. Causing the preparation to face various changes to be not optimal. This is also felt by the world of education. Readiness to learn online (E-learning) set by the government is almost non-existent. Campuses, in this case the lecturer, are required to try to create learning so that it continues even though it is not in campus. Get familiar with online learning. 


\section{Methodology}

This research is descriptive and use a mixed method consisted of a questionnaire- based survey which is administered to undergraduate students. The questionnaire consisted of two parts. The first part of the questionnaire included students' perception about E-learning in COVID-19 pandemic era. The second part consisted of questions about the students' reasons about effective or not the e-learning process in pandemic era. Questionnaire was constructed to answer the research questions which are the perceptions of university's students of using E-learning media since pandemic era and their reasons. The sample of the research $(n=27)$ is the sixth semester undergraduate students from English Education Department of 2019/2020 academic year, Universitas Muhammadiyah Sidenreng Rappang, Indonesia. The first part of questionnaires made use of the Likert scale ranging from $1=$ Strongly Disagree, $2=$ Disagree, 3= Undecided, 4= Agree and 5= Strongly Agree. Neag Centre for Gifted Education and Talent Development University of Connecticut (2007) states that perception affects emotions and behaviours and the emotional and behavioural reactions also help shape the environments and skew ones' beliefs about their environments. Questionnaire for the students give to know their feeling, opinion and thought using the media. The data from the questionnaire were analyzed by using Likert Scale. It aimed to measure the students' opinion.

Beside the part one of questionnaire, part two did to gather more information from students' about factors that influence their perception on the use of E-learning media in COVID-19 pandemic era. The data collected from the questionnaire was analyzed quantitatively and qualitatively.

\section{Findings and Discussions}

\subsection{Students' perception about E-learning in COVID-19 pandemic era}

In findings, the data was analyzed; the students' responses from the question were tabulated and discussed in later chapters. The results show that out from 27 students, $81.5 \%(n=22)$ of the students were female and $18.5 \%(n=5)$ male. Females were the majority of the samples. All of the population $(n=27)$ were sixth semester students of English Education Department, Universitas Muhammadiyah Sidenreng Rappang, South Sulawesi, Indonesia.

\subsection{Students' Perception on the Use of E-learning Media in COVID-19 Pandemic Era}

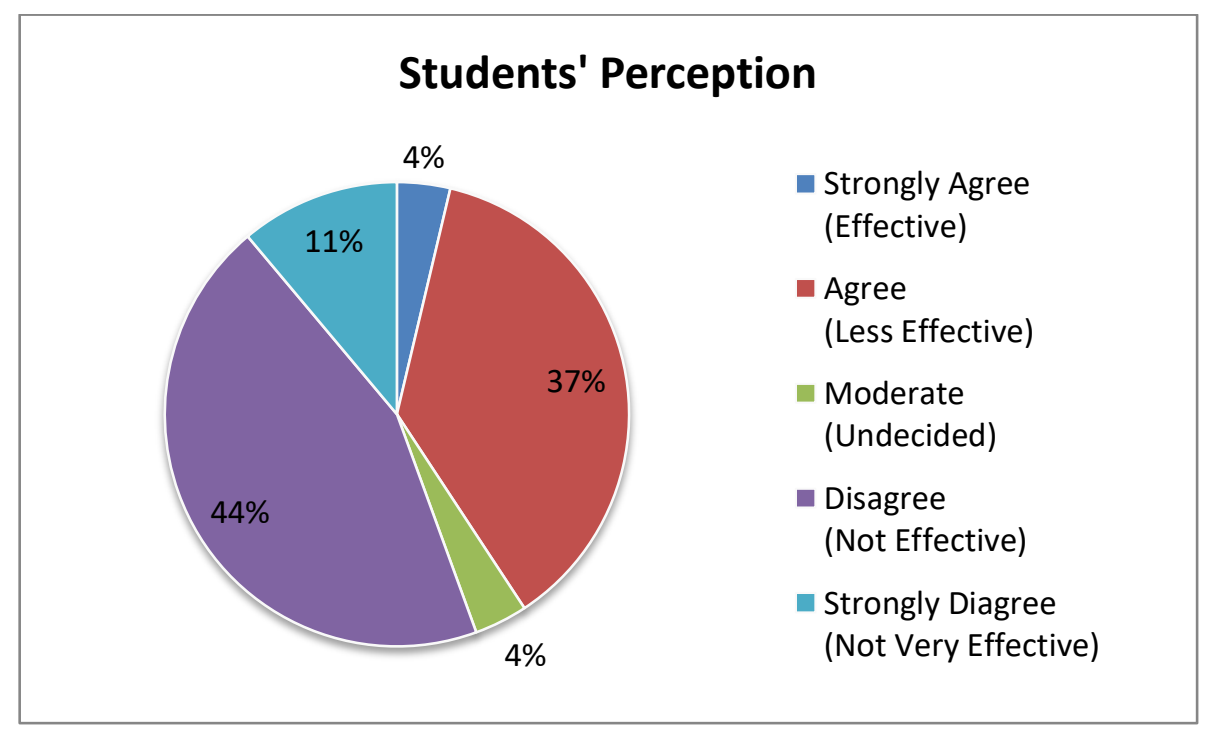

Fig. 1. Students' Perception 
The results of Figure 1 show that students' perceptions about the use of e-learning media in the English learning process during the COVID-19 pandemic were not effective. There is only 1 student who strongly agrees with the current e-learning process, there are 10 students who said the process less effective, 1 student say they are moderate (4\%), 12 students disagree (not effective) and 3 students strongly disagree or said the E-learning is not very effective. This findings show that students still prefer to study on campus directly than learning through online (E-learning) like today.

\subsection{Factors Influenced the Students' Perception on the Use of E-learning Media in COVID-19 Pandemic Era}

There are many factors influenced the students' perception on the use of E-learning media in COVID-19 pandemic era. There are some students' reasons for the answer that using E-learning was not effective in COVID-19 Pandemic era.

1. The signal and network connection

$>$ I say the E-learning method is not effective, because the signal established by the student incompatible so hard to receive a lesson given by the lecturer with the maximum. (S1).

$>$ The existence of network problems that can haunt the process of lecturing E-learning. (S2).

$>$ Limited networks in some student areas so there are some students who cannot participate. (S4).

$>$ Network availability is sometimes a barrier for anyone to access the internet quickly. (S5).

$>$ And the second reason is the internet connection. Yeah we know that in Sidrap, internet connection need to upgrade because it's slow and sometimes it's stuck, and also not all original in Sidrap can reached by internet connection so my friend who live in some rural area, can't join with our class because they have a problem with the internet connection and cannot online in the application. (S10)

2. Limit of quota and expensive

$>$ Obstacle endless quotas and the limitations of money to continuously recharge quotas the internet. (S1).

$>$ Not all telecoms company operating in Indonesia has been established cooperation with the media platforms online learning, so quotas students who were access the content of learning online are rapidly exhausted. (S1)

$>$ Not all students are always able to buy a voucher when their quota runs out. (S2).

$>$ Some of the applications used by lecturers drain too much quota. (S4).

$>$ Not all telecoms company operating in Indonesia has been established cooperation with the media platforms online learning, so quotas students who were access the content of learning online are rapidly exhausted. (S6).

$>$ E-learning methods also consume a lot of data and of course this burdens students in general. (S8).

$>$ With the use of the zoom application sometimes the network must be friendly and take up a lot of quota. (S9).

$>$ And then for the last reason... Honestly this is E-learning is expensive, not gonna lie, a lot of us Complaining about the learning application it use a lot of Internet packet. For example Zoom, I'm using to learn for $40 \mathrm{~min}$ and it takes almost $500 \mathrm{mb}$ of internet packet. Well, that $500 \mathrm{mb}$ of internet, i can use it to watch and practice my listening on YouTube for almost 2 hours in 240p quality. I think that's enough to explain my "Denial" of this E-Tasking. (S10).

3. Lack of lecturers methods

$>$ The lecturers not explain the material but immediately gave the task. (S1).

$>$ I say the E-learning methods is not effective, because in E-Learning methods, Still there is a lecturer who inattentive when the schedule has been in which, while students have been waiting and log in to the learning online system until the time finished. But it don't was counted as the learning process. (S1).

$>$ Reduced explanation of the material from the lecturer. (S2).

$>$ In my opinion E-learning is still ineffective because lecturers have not mastered learning methods well so students do not understand. (S3). 
$>$ There are some lecturers who only give assignments in an application but have not explained so that students have difficulty in completing assignments. (S4).

$>$ Besides that, the use of E-learning also has disadvantages. For example, with the presence of online lectures, some lecturers are more directed to give assignments without giving explanations of learning material. (S5).

> In my opinion, about the E-learning method currently applied by lecturers to students is not effective, because: (1) There are some lessons that are difficult to understand so it is not effective if explained only by using E-learning methods, and each student has a different understanding that there are those who understand quickly and some who are slow. (2) Some lecturers have not been able to use/ operate the Elearning application so the lesson time is passed. (S8).

$>$ I think it's not effective, because in a situation like this it's not possible to do direct learning. So the lecturer provides teaching through applications, applications such as zoom and WebEx. In the use of applications such as zoom, sometimes I do not focus, because it doesn't communicate directly with lecturers or friends. So there is no direct interaction or communication. And also doing a presentation with the zoom application I think is ineffective because when a group does the presentation it requires concentration and a lot of communication with group friends. In learning with the application only as a form of face to face and absent. (S9).

$>$ If you asking me are this E-learning effective or not, I think it's not effective for us. The first reason why I say that is not effective for us because, as long as I see there are some lecturers who cannot use elearning and they don't even know what kind of application that we can use to learn. That's the first case. And then the next. Relating to the first point, the lecturer that I mean cannot use the E-learning is sharing problem with the students, i mean... When they don't know how to use the application, they change it become task that irrational. They give us a task as if all we have to do in home is doing his task... Ohhh c'mon... The fourth Semester program 10 courses imagine that when that 10 lecturer give us a big task and said "The deadline is 2 weeks, how come you can't finish it" it give us more stress honestly. (S10).

4. Lack of students' motivation

$>$ In my opinion E-learning is still ineffective because students are sometimes too relaxed in learning so learning is not efficient. (S3).

$>$ E-learning makes some students lazy with the reason they can do or take lectures online even lying down even though. (S4).

$>$ And students who do not have high learning motivation will experience failure. (S7).

5. Limitation of time

$>$ And learning time is not always on time so a lot of time is wasted. (S3).

$>$ Every learning process is limited with time. (S8).

6. Lack of interaction

$>$ In the midst of the outbreak of COVID-19 all lectures in Indonesia were closed and transferred to Elearning which in my opinion there are several things that make this E-learning lecture ineffective because interaction between lecturers and students is reduced. (S2).

$>$ In my opinion, E-learning in the current situation is not effective, although it can avoid the virus by staying at home. Some disadvantages of e-learning are lack of interaction between lecturers and students, so that it can slow the formation of values in the learning process. (S4).

$>$ In my opinion, about the E-learning method currently applied by lecturers to students is not effective, because direct interaction between teachers and students will be reduced. (S7).

From the findings and explanation above, the researchers can say that the use of E-learning media in pandemic COVID-19 era is not effective according to the students. Most of students give negative perception about it. This is indicated by students' perceptions of the use of E-learning at this era. The various types of E-learning applications do not guarantee students enjoy the learning process. There are many reasons influenced the students' perceptions on the use E-learning as media in learning process while this pandemic COVID-19 era. 


\section{Conclusion}

This study showed that the students' perceptions of using E-learning in learning English process while the COVID-19 pandemic era. The use of that media in E-learning process is less interested to the students. It was proved by the results of students' perception. These scores are categorized as disagree or negative scores of perceptions if they are confirmed by using a Likert Scale. There is only 1 student who strongly agrees with the current e-learning process or said that the E-learning in pandemic COVID-19 era is effective, there are 10 students who said the E-learning is less effective, 1 students say they are moderate (4\%), 12 students said E-learning is not effective and 3 student said Elearning is very not effective. There are many factors influenced the students' perception on the use of E-learning media in COVID-19 pandemic era such as, the signal and network connection; limit of quota and expensive; lack of lecturers methods; lack of students' motivation; limitation of time; and lack of interaction.

\section{Acknowledgements}

I would like thanks to students of English Education Department, Universitas Muhammadiyah Sidenreng Rappang for their contribution and cooperation.

\section{References}

Atmowardoyo, H., Weda, S., \& Sakkir, G. (2020). Information Technology used by Millennial Good English Language Learners in an Indonesian University to Improve their English Skills. Solid State Technology, 63(5), 9532-9547.

Conference, B. I., Jamin, A., \& Mudra, H. (2019). Curriculum Development in Islamic Higher Education : Strengthening Characters of. (2001), 49-56.

Hsu, H. Y., Wang, S. K., \& Comac, L. (2008). Using audioblogs to assist English-language learning: An investigation into student perception. Computer Assisted Language Learning, 21(2), 181-198.

Kasmawati, K., \& Sakkir, G. (2020). Improving Students Reading Comprehension Through "Survey, Question, Reading, Recite, Review (SQ3R)" Strategy. Interference: Journal of Language, Literature, and Linguistics, $1(2), 92-99$.

Maulina, M. (2019, April). Gender differences in language development, acquisition, comprehension, and production. In Proceedings of the 65th Teflin International Conference (Vol. 65, No. 01).

Pratama, H., \& Yusro, A. C. (2016). Implementasi WhatsApp mobile learning untuk meningkatkan hasil belajar mahasiswa pokok bahasan Pengenalan Komponen Elektronika. Jurnal Pendidikan Fisika dan Keilmuan (JPFK), 2(2), 65-69.

Prensky, M. (2001). Digital natives, Digital immigrants Part 1. On the Horizon, 9(5), 1-6.

Rahman, H., Sakkir, G., \& Khalik, S. (2020). Audio-Lingual Method to Improve Students's Speaking Skill At Smp Negeri 1 Baranti. La Ogi: English Language Journal, 6(1), 15-21.

Sakkir, G. (2011). Improving Students' Writing Ability through Story Pictures at SMAN 2 Panca Rijang Sidrap (Doctoral dissertation, Thesis. Makassar: Graduate Program State University of Makassar).

Sakkir, G. (2018). Pengembangan Modul Pengajaran Menulis Berbasis Facebook (Doctoral dissertation, Pascasarjana).

Sakkir, G. (2018). Writing: Beginner. Deepublish.

Sakkir, G. (2020). The Effectiveness of Pictures In Enhance Writing Skill of Senior High School Students. Interference: Journal of Language, Literature, and Linguistics, 1(1). 
Sakkir, G., \& Dollah, S. (2019). Facebook-Based Writing Instructional Material In English Class: Lecturers'perception. SELTICS, 2(2), 76-83.

Sakkir, G., \& Dollah, S. (2019). Measuring students'writing skills using Facebook group application in EFL context. International Journal of Humanities and Innovation (IJHI), 2(3), 69-72. https://doi.org/10.33750/ijhi.v2i3.43

Sakkir, G., Dollah, S., \& Ahmad, J. (2020). Favorite E-Learning Media in Pandemic COVID-19 Era. Jurnal Studi Guru dan Pembelajaran, 3(3), 480-485.

Sakkir, G., Dollah, S., \& Ahmad, J. (2020). Students' Perceptions toward Using YouTube in EFL Classrooms. Journal of Applied Science, Engineering, Technology, and Education, 2(1), 1-10.

Sharif, R. (2005). PC skills, English crucial, Kong tells grads. The Star Online.

Snelson, C. (2011). YouTube across the disciplines: A review of the literature. MERLOT Journal of Online Learning and Teaching, 7(1), 159-169.

Stone, S., \& Logan, A. (2018). Exploring students' use of the social networking site WhatsApp to foster connectedness in the online learning experience. Irish Journal of Technology Enhanced Learning Ireland, $3(1), 42-55$.

Syatriana, E., \& Sakkir, G. (2020). Implementing Learning Model Based On Interactive Learning Community For Efl Students Of Muhammadiyah University. ELT Worldwide, 7(1), 24-30.

Umar, A., Madani, M., Farida, U., Yusriadi, Y., Tamsa, H., Yahya, M., ... \& Misnawati, M. (2019). One-Stop Service Policy as a Bureaucratic Reform in Indonesia. Academy of Strategic Management Journal, 18(2), 1-12.

Web Analytics Association. (2006) Google.com tops list of college students' favorite websites- But only through purchase of YouTube.com. 